\title{
WEAR CHARACTERISTICS AND DEFECTS ANALYSIS OF FRICTION STIR WELDED JOINT OF ALUMINIUM ALLOY 6061-T6
}

\section{CHARAKTERYSTYKA ZUŻYCIA I ANALIZA USZKODZEŃ ZŁĄCZA ZE STOPU ALUMINIUM 6061-T6 ZGRZEWANEGO TARCIOWO Z PRZEMIESZANIEM}

\begin{abstract}
This paper deals with the wear characteristics and defects developed during friction stir welding at different process parameter of aluminium alloy (AA) 6061-T6 having thickness $6 \mathrm{~mm}$. Four welded samples are prepared with rotational speed $500 \mathrm{rpm}$, $710 \mathrm{rpm}$, $1000 \mathrm{rpm}$ and with welding speed of $25 \mathrm{~mm} / \mathrm{min} \& 40 \mathrm{~mm} / \mathrm{min}$. Welded samples and base material are put in wear condition under grinding machine for $120 \mathrm{~s}$. Material removal is measure by taking the difference of weight before and after wear. Different types of defects and fracture are observed on the wear surface. These defects and fractures are analysed under field emission scanning electron microscope (FESEM). It is concluded that material removal from welded sample is less compared to base metal, hence wear resistance increases after friction stir welding.

Keywords: Friction stir welding (FSW), Wear, Defect, Grinding Machine, Field Emission Scanning Electron Microscope (FESEM)

Praca dotyczy charakterystyki zużycia i uszkodzeń podczas zgrzewania tarciowego z przemieszaniem stopu aluminium (AA) 6061T6 o grubości $6 \mathrm{~mm}$ dla zmiennych parametrów. Cztery zgrzewane próbki były wykonane z prędkościq obrotowa 500 obr/min, 710 obr/min, $1000 \mathrm{obr} / \mathrm{min}$ dla prędkości zgrzewania $25 \mathrm{~mm} / \mathrm{min}$ i $40 \mathrm{~mm} / \mathrm{min}$. Zgrzewane próbki i materiat bazowy byly poddawane zużywaniu za pomoca szlifierki w czasie 120 s. Ubytek materiału mierzono jako różnicę wagi przed i po zużywaniu. Różne rodzaje wad i pęknięć zaobserwowano na zużytej powierzchni. Wady i pęknięcia analizowano za pomoca mikroskopu polowego (FESEM). Stwierdzono, że ubytek materiału ze zgrzewanych próbek jest mniejszy w porównaniu z ubytkiem dotyczacym materiału bazowego. Zwiększa się więc odporność na zużycie po zgrzewaniu tarciowym z przemieszaniem.
\end{abstract}

Stowa kluczowe: Zgrzewanie tarciowe z przemieszaniem, zużycie, uszkodzenie, szlifierka, mikroskop polowy.

\section{Introduction}

Friction stir welding (FSW) is developed and patented by Mr. Wayne Thomas at The Welding Institute (UK) in the year 1991 [28]. It is a solid state joining technique at which materials are joined below their melting point. Hence compared to other traditional techniques it is energy efficient, versatile and environment friendly. Aluminium alloys especially $2 \mathrm{XXX}$ and 7XXX series are difficult to weld by conventional fusion welding process because of poor solidification and porosity in fusion zone. Hence aluminium alloys are easily welded by FSW process [23]. Friction stir welding quality is determined and controlled by the process parameters like rotational speed, welding speed, plunge depth etc. Figure 1 shows the schematic diagram of friction stir welding process. In this process material that is going to be joined is fixed on bed with the help of fixtures and a non consumable rotational tool plunges through the material. There is generation of friction heat due to contact between tool and work piece, which brings the material in semi solid state. Due to stirring action and consolidated pressure by the tool the semi solid material gets joined [7].

Won-Bae Lee et al. studied the microstructures and wear property of friction stir welded $\mathrm{AZ} 91 \mathrm{Mg}$ alloy/SiC particles reinforced composite (AZ91/SiC/10p). They found an improvement in the wear property of the weld zone as compared to base metal. They concluded

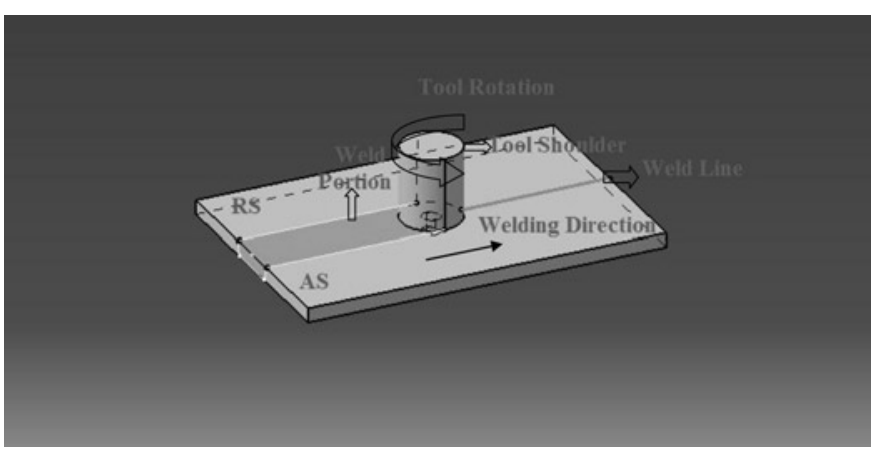

Fig. 1. Schematic drawing of friction stir welding

the wear resistance within the weld zone, as evaluated by the specific wear loss, was superior, as compared to the base metal [19]. R. Palanivel et al. developed an empirical relationship between FSW process parameter and wear resistance of friction stir welded joint of two dissimilar aluminium alloy AA5083H111-AA6351T6. It was found that wear resistance increases as tool rotational speed, welding speed and axial force increases up to certain level then it starts decreasing. It was also observed that joints fabricated using straight pin profiles yielded highest wear resistance due to intense plastic flow and mixing of dis- 
similar alloys as compared to tapered pin profile tool [24]. Dinaharan I. et al. developed an empirical relationship to predict the effect of process parameter on sliding wear behaviour of butt joints of friction stir weld AA6061/ 0-10 wt.\% $\mathrm{ZrB}_{2}$ composites. They concluded that wear rate decreases as tool rotational speed, welding speed and axial force increases. After that further increase in these process parameter increases the wear rate. They also studied the scanning electron microscopy (SEM) micrographs of wear surface [6]. Prakash et al. studied the tribological behaviour i.e. dry sliding wear characteristics using a computer aided pin on disc wear testing machine of friction stir processed Al 6061 sheet with metal reinforced. They concluded that wear rate decreased as weight percentage of $\mathrm{Al}_{2} \mathrm{O}_{3}$ increased. Through SEM they studied the wear surfaces and observed wear tracks that are covered with the compact debris and delamination [26]. Jankauskas V. et al. analysed the influence of welded layers composition on the abrasive wear mechanism of friction couples "hard layer-steel". They investigated the arc welded layer's strength, surface morphology; chemical and structural composition and abrasive wear resistance. Wear was determined by weighing the samples before and after the test. The microstructure was analysed with the optical metallographic microscope and morphology of friction surfaces were analysed with SEM [12]. As per literature it can be found that researchers studied the wear characteristics of different friction stir welded joints. Some have compared the wear resistance property of weld zone compared to base material and concluded that wear resistance property is better at weld zone compared to base material.

Karam et al. study the possibility of joining two dissimilar alloy i.e. A319 and A413 using friction stir welding. They examined the weld bead visually in which they found flash formation on upper surface. They found formation of tunnel defect through X-ray radiograph and defects at macrostructure analysis on sample prepared at high welding speed [15]. Joulo T. Le et al. have investigated the fatigue strength and failure mechanism of defect free and flaw bearing friction stir butt-weld of $3.1 \mathrm{~mm}$ thick AA2198-T8 Al-Li-Cu alloy via S-N curve. Under this study detailed fractography was carried out to link fatigue crack initiation sites and propagation paths to the presence of defects on monotonic loading. They used scanning electron microscope for the fracture surface examination and also for the defect observation. They observed the intergranular cracks and concluded that fracture occurs always from inter granular cracks [13]. Dehghani M. et al. has joined the Al 5186 to mild steel using friction stir welding technique. They investigated the effect of process parameters on defects like tunnel formation, cavity and porosity. At higher pin diameter and with lower welding speed tunnel formation was observed but as pin diameter decreases and welding speed increases such defects could be avoided. Also the threaded pin profile can minimise the formation of cavity [3]. Kadlec Martin et al. studied the effects of kissing bond defect on the tensile and fatigue properties of 7475-T7351 friction stir welds with respect to a reference weld without any flaws and a base material. They determined the defects size by investigating various kissing bond defects. Using SEM they investigated a new process of crack initiation and propagation from the kissing bond surface rather than from its end [14]. Ramulu P. Janaki et al. analyzed the effect of process parameter on the formation of internal defects of friction stir welded joint of AA $6061 \mathrm{~T} 6$ having thickness $6.1 \mathrm{~mm}$. They have discussed the defect due to less tool plunge, insufficient heat generation and plastic deformation. They concluded that higher welding speed, higher rotation speed and higher plunge depth are preferred for producing a defect free weld. They also optimized the welding parameter for producing the internal defect free welds [27]. Li J. Q. et al. has studied the defects developed at different rotational speed for the external non-rotational shoulder assisted friction stir welding on 2219T6 aluminium alloy. They investigated the morphology of the cavity defect with high magnification. They observed the cavity defect close to the top surface of the weld [20]. Chen Hua Bin et al. made an at- tempt to investigate the formation of defect like void on friction stir welded joint of 5456 aluminium alloy. They used optical microscopy and scanning electron microscope to analyse these defects [2]. Zhang Huijie et al. has characterized and proposed mechanism for formation of welding defects in underwater friction stir welded $7.5 \mathrm{~mm}$ thick 2219-T6 aluminium alloy. They analysed the defects such as voids and grooves through the material flow patterns. They concluded that welding defects can occur at both low as well as high rotational speed. They studied the high magnification images of welding defects formed under different process parameters [32]. Janjic M. et al. investigated the tunnel defect on the advancing side of friction stir welded joint of AA 6082-T6. They put it in the category of density error caused due to insufficient transport of material around the pin [11]. Podrzaj P. et al. studied different types of defects at friction stir welding. They discussed defects like tunnels, voids, surface grooves, excessive flash, surface galling, nugget collapse and kissing bond. They have given the energy input as main reason for these defects [25]. Dimic Ivana et al. has conducted three dimensional finite element analysis to quantify the influence the weld defects on integrity of pipe elbows subjected to internal pressure. They concluded that local defects reduce the load carrying capacity and deformation ability of a piping system. They discovered the defect through ultrasonic measurement [5]. From the literature it can be observed that researchers have examined the defects in friction stir welded joints. Some have found the defects like voids, cavity and tunnel defects.

Wear characteristics and defects analysis is important in technical diagnostics which includes assessment of the technical condition of machines parts by studying the properties of its work processes. Failure of machine parts can be avoided by proper welded joints. Through root cause analysis of defects maintenance of machine parts reduces. The diagnostics is important for mining, metallurgy, processing industry and materials science [16, 9, 8, 30, 17, 4, 10, and 31]. Mazurkiewicz described the most popular diagnostic systems used in the maintenance of internal transport conveyors system and also presented a new method of computer-aided maintenance of such systems. He found that with the help of described monitoring system maintenance diagnosis of a single belt conveyor or an entire transport system enables effective assessment of the current state of bonded joints [22]. Wang explained that demands of spare parts are usually generated by the need of maintenance either preventively or at failures. He suggested that proper planned maintenance intervention can reduce the number of failures [29].

Hence from above findings of all researchers it can be summarized that wear of any welded component causes defect. Defects in any welded part can arise due to improper selection of process parameter or due to wear of the welded part. These wear and defects causes the failure of any welded part. Therefore there is need of maintenance either post failure or to prevent this failure.

This paper deals with the study of wear characterization and investigation of different weld defects generated in friction stir welded joint of aluminium alloy 6061-T6. The aim of this paper is to study the effect of process parameter with the material removal during wear condition and comparing it with base material under same condition. FSW samples are put in wear condition in grinding machine to create the extreme real harsh wear condition. These welded samples will face such type of harsh wear condition at automobile or shovel teeth. Under this paper different types of defects are studied under FESEM. These defects may arise in friction stir welded joints when welded joints are put in wear condition. AA 6061-T6 is a light weight aluminium alloy used in rail coaches, truck frames, ship building, civil bridges, for aerospace applications including helicopter rotor skin etc. 


\section{Experimental procedure}

The friction stir welding set-up is developed on HMT 1U-make milling machine. SS 410 stainless steel was selected as FSW tool material and $6 \mathrm{~mm}$ thick AA $6061 \mathrm{~T} 6$ is chosen as working material. The welding samples are prepared at four process parameters as given in Table 2. Friction stir welded sample and base metal sample of dimension $30 \mathrm{~mm}$ X $25 \mathrm{~mm}$ are put in wear condition with the help of grinding machine for $120 \mathrm{~s}$ as shown in Figure 2. Specification of grinding wheel is shown in below Table 1 .

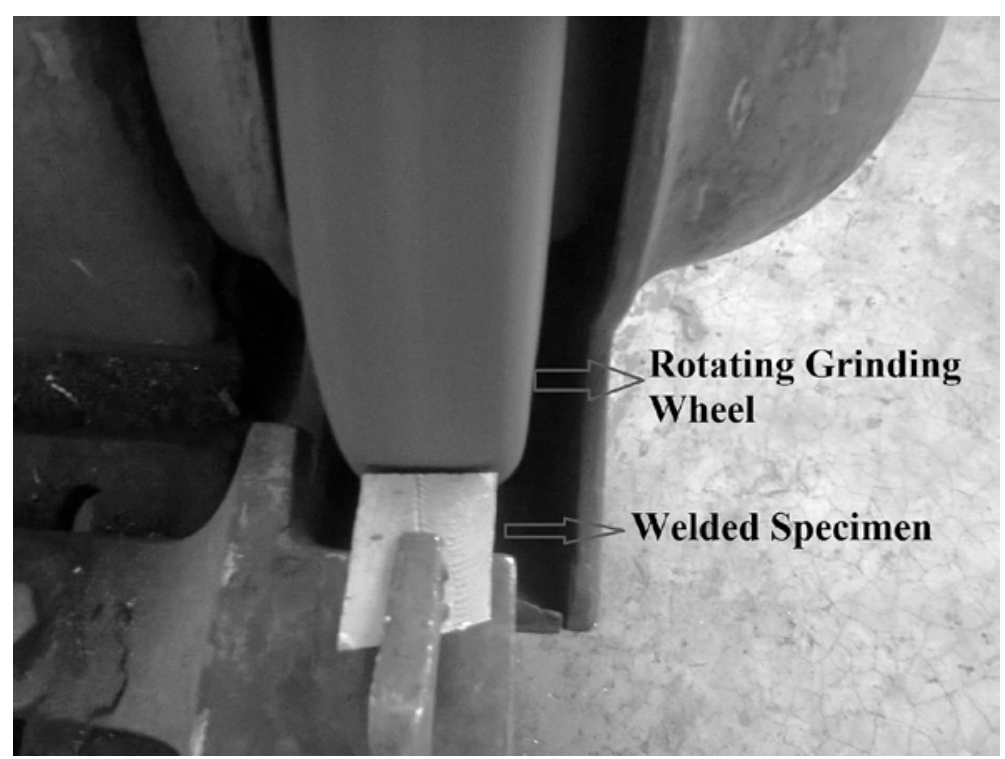

Fig. 2. Experimental setup

Table 1. Specification of grinding wheel

\begin{tabular}{||c|c||}
\hline Rotational Speed (N) & $1600 \mathrm{rpm}$ \\
\hline Diameter of grinding wheel (D) & $130 \mathrm{~mm}$ \\
\hline Width of grinding wheel & $40 \mathrm{~mm}$ \\
\hline Time duration of test & $120 \mathrm{sec}$ \\
\hline
\end{tabular}

With the help of precision weighing machine initial weight of all samples i.e. weight before wear and final weight of all sample i.e. weight after wear is measured. With the difference in final weight and initial weight material removal from each sample is find out to study the abrasive wear phenomena of welded sample.

Table 2 shows the detail of welded sample prepared at their corresponding process parameter.

During the friction stir welding experiment, temperature is observed with the help of Infrared camera of CHAUVIN ARNOX C.A. 1888 .

Table 2. Process parameter of specimen

\begin{tabular}{|c|c|c|c|c||}
\hline $\begin{array}{c}\text { SI. } \\
\text { No. }\end{array}$ & $\begin{array}{c}\text { Sample } \\
\text { no. }\end{array}$ & Type & $\begin{array}{c}\text { Rotational } \\
\text { Speed }(\mathrm{rpm})\end{array}$ & $\begin{array}{c}\text { Welding Speed } \\
(\mathrm{mm} / \mathrm{min})\end{array}$ \\
\hline 1. & 1 & Welded Sample & 500 & 25 \\
\hline 2. & 2 & Welded Sample & 710 & 25 \\
\hline 3. & 3 & Welded Sample & 1000 & 25 \\
\hline 4. & 4 & Welded Sample & 710 & 40 \\
\hline 5. & 5 & Base Material & & \\
\hline
\end{tabular}

\section{Result \& Discussion}

\subsection{Maximum temperature}

Maximum temperature during the process can be measured with the help of thermal images taken from infrared camera. Figure 3 shows the maximum temperature generated during the experiment for sample no 2. Table 3 gives the maximum temperature generated at all the four process parameters.

From Table 3 it can be concluded that maximum temperature achieved during the process is maximum for sample 3. Hence it can be derived that temperature obtained during the process increases as rotational speed increases.

\subsection{Theoretical formulation of material removal during grinding operation}

Theoretically material removal rate (MRR) in case of grinding operation can depend upon width of cut, depth of cut and feed rate of work piece:

Hence,

$$
\operatorname{MRR}\left(\frac{m m^{3}}{s}\right)=d^{*} w^{*} v
$$

where: $d=$ depth of cut,

$$
\begin{aligned}
& w=\text { width of cut, in this case it is } 25 \\
& \mathrm{~mm} \text {, } \\
& v=\text { feed rate of work piece. }
\end{aligned}
$$

Since rotational speed of grinding wheel $(\mathrm{N})=1600 \mathrm{rpm}$.

where: $\quad\left(\frac{m}{s}\right)=(* D * N) / 60$,

Now, by inserting value of $v$ from eq (2) to eq (1),

therefore

$$
\operatorname{MRR}\left(\frac{m^{3}}{s}\right)=0.27 * d
$$
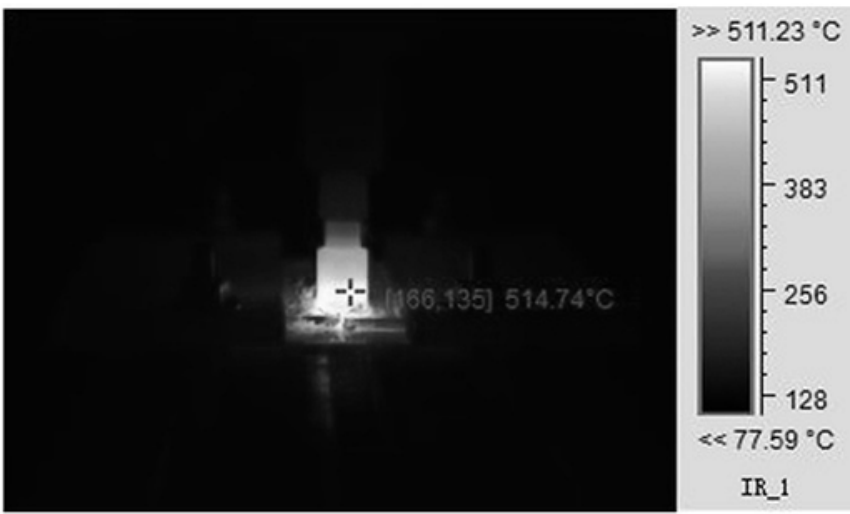

Fig. 3. Infrared image of FSW

Table 3. Maximum temperature attained at different welding condition

\begin{tabular}{|c|c|c|}
\hline SI. No. & Sample no. & Maximum Temperature \\
\hline 1. & 1 & 482.00 \\
\hline 2. & 2 & 518.57 \\
\hline 3. & 3 & 539.07 \\
\hline 4. & 4 & 515.4 \\
\hline
\end{tabular}


Material removal in, $\quad 120 s\left(m^{3}\right)=32.67 * d$.

Hence,

$$
\operatorname{removed}(\mathrm{Kg})=88.21 * d,
$$

Since density of aluminium is taken as $\left(\rho_{\mathrm{al}}\right)=2.7 \mathrm{Kg} / \mathrm{m}^{3}$.

So,

$$
\operatorname{mass} \operatorname{removed}(\mathrm{mg})=88.21 * 10^{6} * d
$$

Hence from equation (6) material removal depends on depth of cut. In this experiment depth of cut is not known. Since, there is only surface contact between grinding wheel and work piece.

\subsection{Experimental analysis of wear}

Material removal is obtained by measuring the weight of all five specimens before and after wear. Material wear from all five samples are plotted in Figure 4.

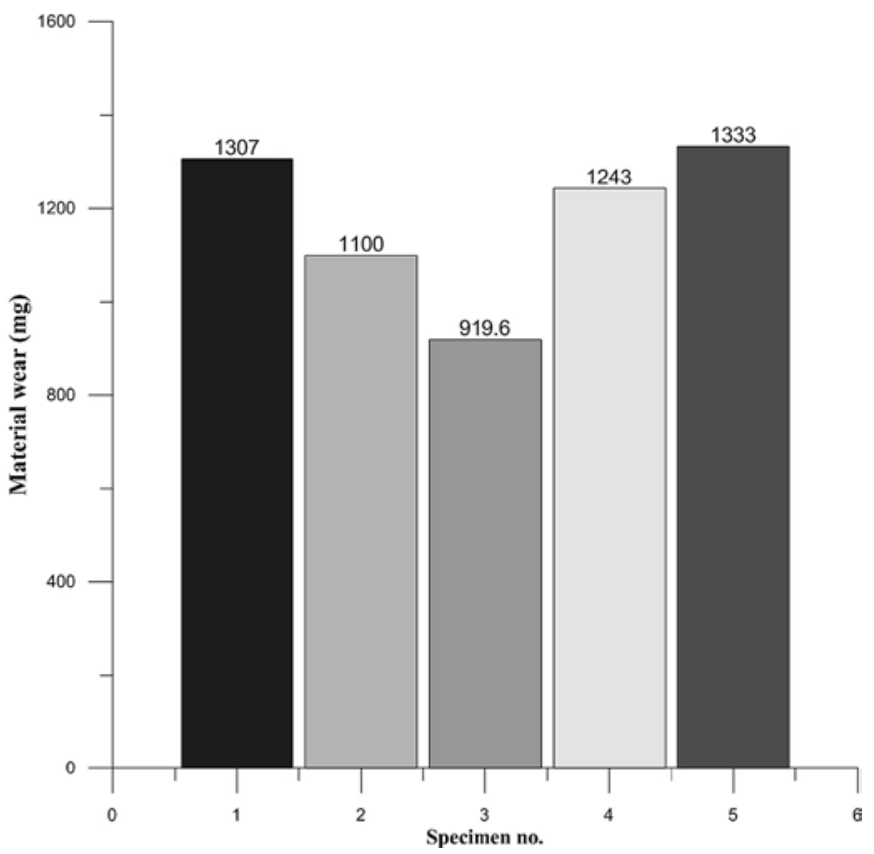

Fig. 4. Comparison of material removal of different welded sample with base metal

From the Figure 4 maximum material removals can be observed for sample no 5 i.e. base metals as compared to welded samples. Hence it can be concluded that wear resistant of welded material is more than that of base material. The reason for such variation is that friction stir welding occurs at a temperature below the melting point of material, so there is no chance of second phase formation. Hence material gets heat treated, so wear resistance property increases. From the above graph it can be observed that material removal is lowest in case of sample no 3 i.e. at $1000 \mathrm{rpm}$ and $25 \mathrm{~mm} / \mathrm{min}$. It implies that best welding has occurred in this case. Since for higher rotational speed and lower welding speed, heat generated is maximum; as clear from Table 2, so material easily stirs and mixed. It is clear that material removal in case of sample no 4 is more than that of sample no 2 . Hence it can be concluded that for same rotational speed as welding speed increases quality of weld decreases, since temperature developed reduces as given in Table 3 .

\subsection{Defects found in welded sample}

After welding the samples through visual inspection defects are observed on the welded plates. These defects caused the rejection of welded plates through visual inspection only.

\subsubsection{Exit hole and Flash}

Friction stir welding process can be sub divided in three phase i.e. plunging in, welding and plunging out. In the plunging out step tool is taken out of the work piece. When tool is taken out of the work piece an exit hole is left at that place. This phenomenon is shown in the Figure 5 of sample 3.

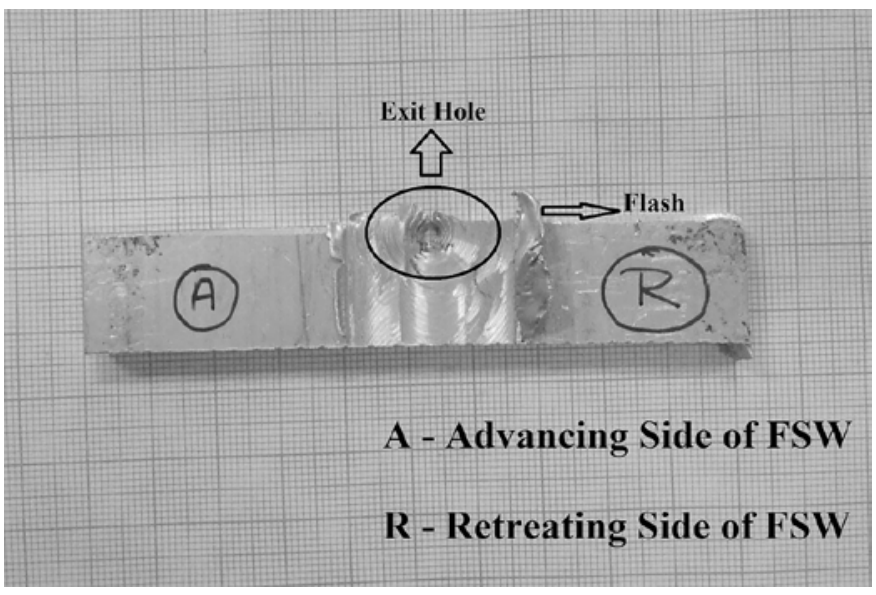

Fig. 5. Exit hole and flash

Exit hole phenomena is observed during all the process parameters. So that amount of material is wasted every time. It is observed that size of exit hole is equal to that of pin size. In Figure 3 at the weld joint area extra material is observed known as flash. The reason for the flash formation is the excessive heat generation. Excessive heat generation leads to the thermal softening of the work piece beyond the boundary of tool shoulder. Hence upper layer of the material come out forming an excessive surface known as flash. Consequently this leads to the thinning of the material in the weld area. Hence at the weld root area, pin starts making contact with the backing bar which causes rupture of material. Ultimately it will damage both the pin and backing bar.

Due to low heat generation, material doesn't get soft. Hence tool is not able to stir and mix the material. So, improper weld result. In the Figure 6, which is the weld joint at tool rotational speed $500 \mathrm{rpm}$ and

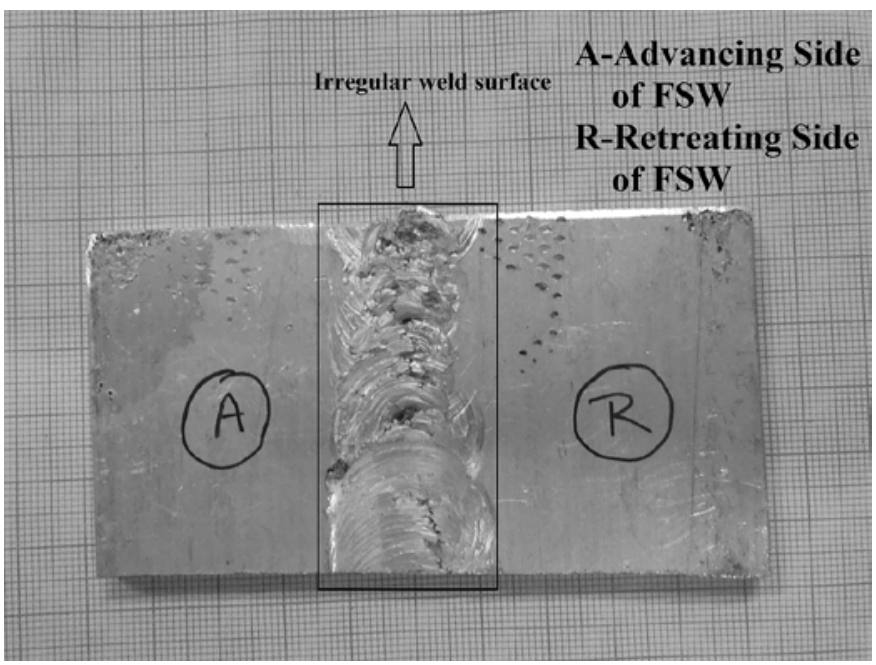

Fig. 6. Irregular weld surface 
weld speed $40 \mathrm{~mm} / \mathrm{min}$, irregular weld surface can be observed from the visual inspection. The reason for such surface is less heat generation due to lower rotational speed and high welding speed [18]. Hence this sample is rejected.

\subsection{Defects generated during wear}

After putting the welded sample in wear condition, several defects are observed. These defects are one of the major causes behind the failure of any friction stir welded structure. So, for the efficient performance of any welded joints these defects must be minimised.

\subsubsection{Fracture along the welding direction on back side of plate}

It is observed that when welded samples are put in the wear condition defects are noticed. A fracture is observed on the back side of plate along the welding direction for sample 1. It shows that at low

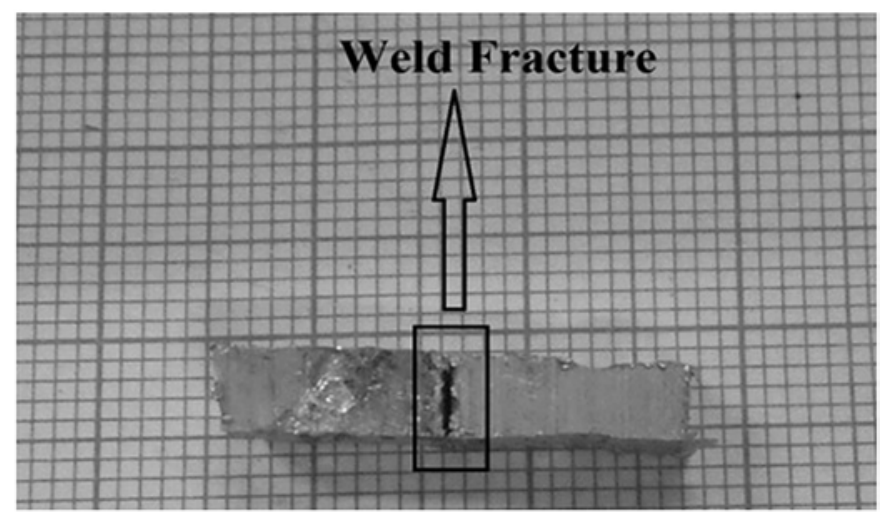

Fig. 7. Weld fracture

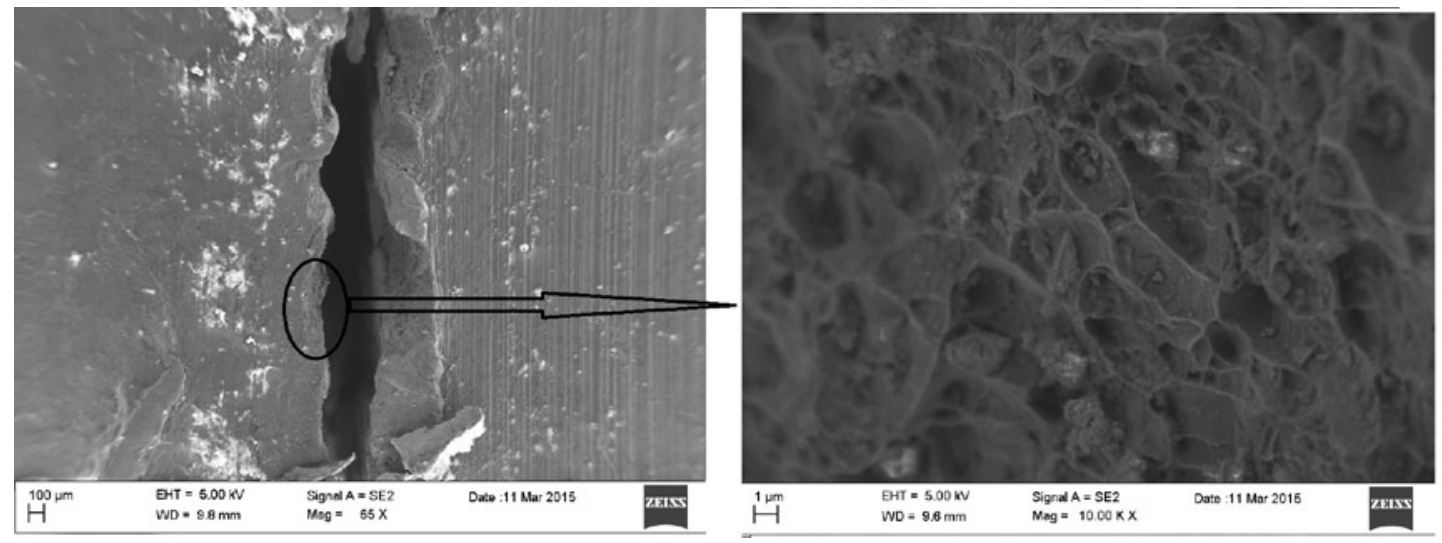

Fig. 8. FESEM image of fracture surface

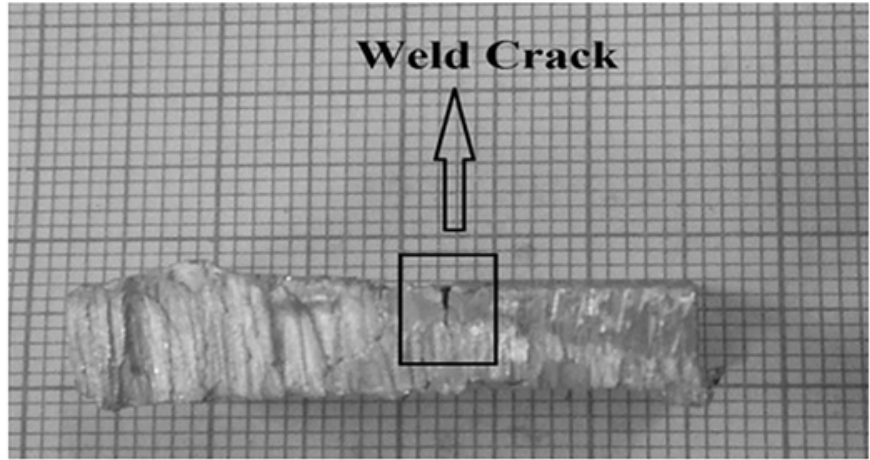

Fig. 9. Weld crack

terized with a lot of dimples, which clearly shows the ductile failure mechanism and ductile fracture morphology reveals that the metallic bonding is performed in this region [33].

\subsubsection{Crack propagates along the thickness as seen from the thickness}

Welded sample 4 put in wear condition, abrasive wear phenomena was observed. After the process when its cross-section was observed there is a propagation of crack along the thickness as shown in Figure 9. FESEM image of the crack is taken and it is shown in Figure 10.

From Figure 10 it is clear that crack propagates along the thickness after wear. It is one of the major causes for the failure of any welded joint [1]. Rectangular part is further magnified and it is seen in the FESEM in the right figure. It can be observed that surface has broken into small particles and hence propagating the crack.

\subsubsection{Porosity}

In sample 2, porosity is observed near the surface as shown in Figure 11.

Porosity is being observed under FESEM as shown in Figure 12.

Figure 12 shows the porosity on the wear surface. It can be observed from the Figure that due to grinding wear surfaces are overlapped to one another. Here also it can be observed that surfaces are broken into segments to form the pores. welding speed due to inadequate amount of heat generated, welded part may fail when put in severe working condition. Figure 7 shows the fracture in sample 1.

Figure 8 shows the FESEM image of fracture surface shown in Figure 7. This clearly shows the failure of the welded part.

Circular part is further magnified and seen on the FESEM. It is clear that the fracture surface is charac-

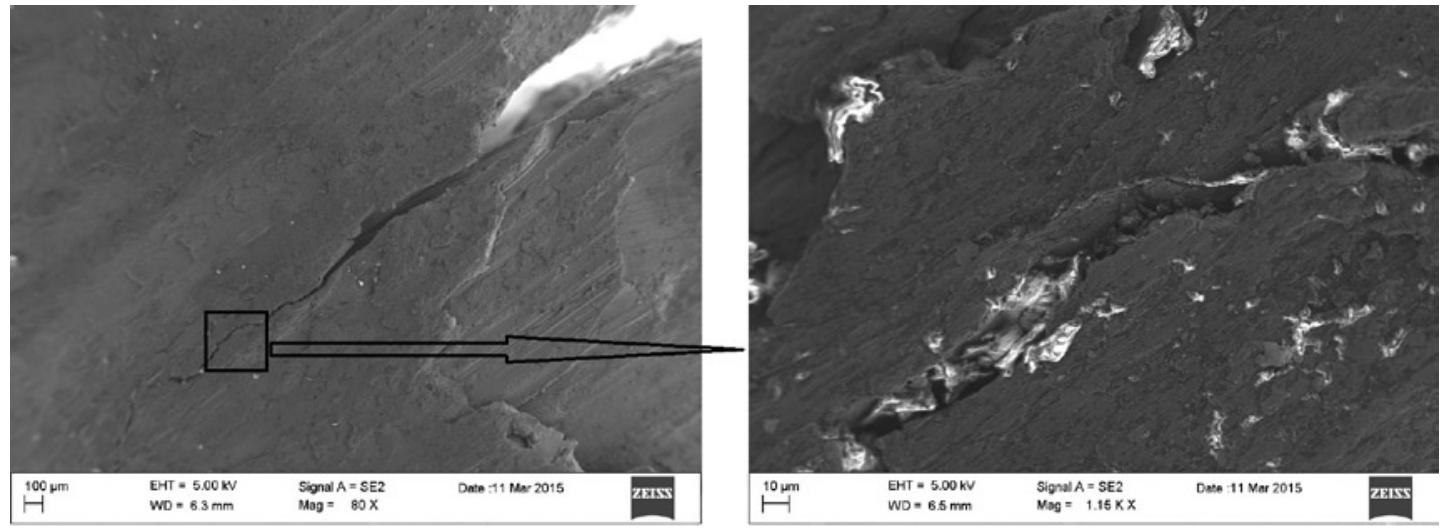

Fig. 10. FESEM image of weld crack 


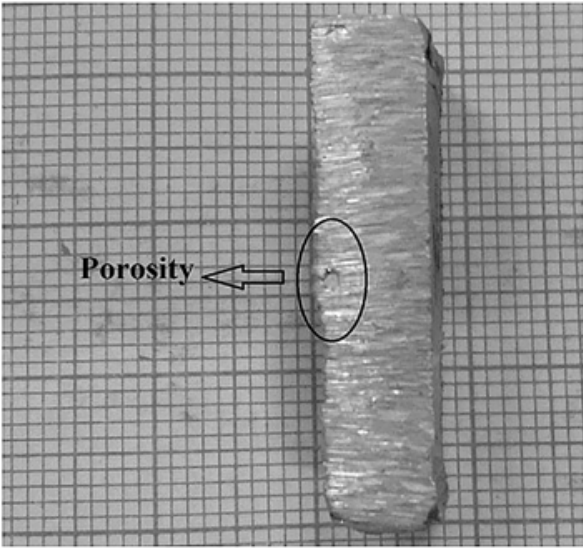

Fig. 11. Porosity

Fig. 13. Holes on weld surface
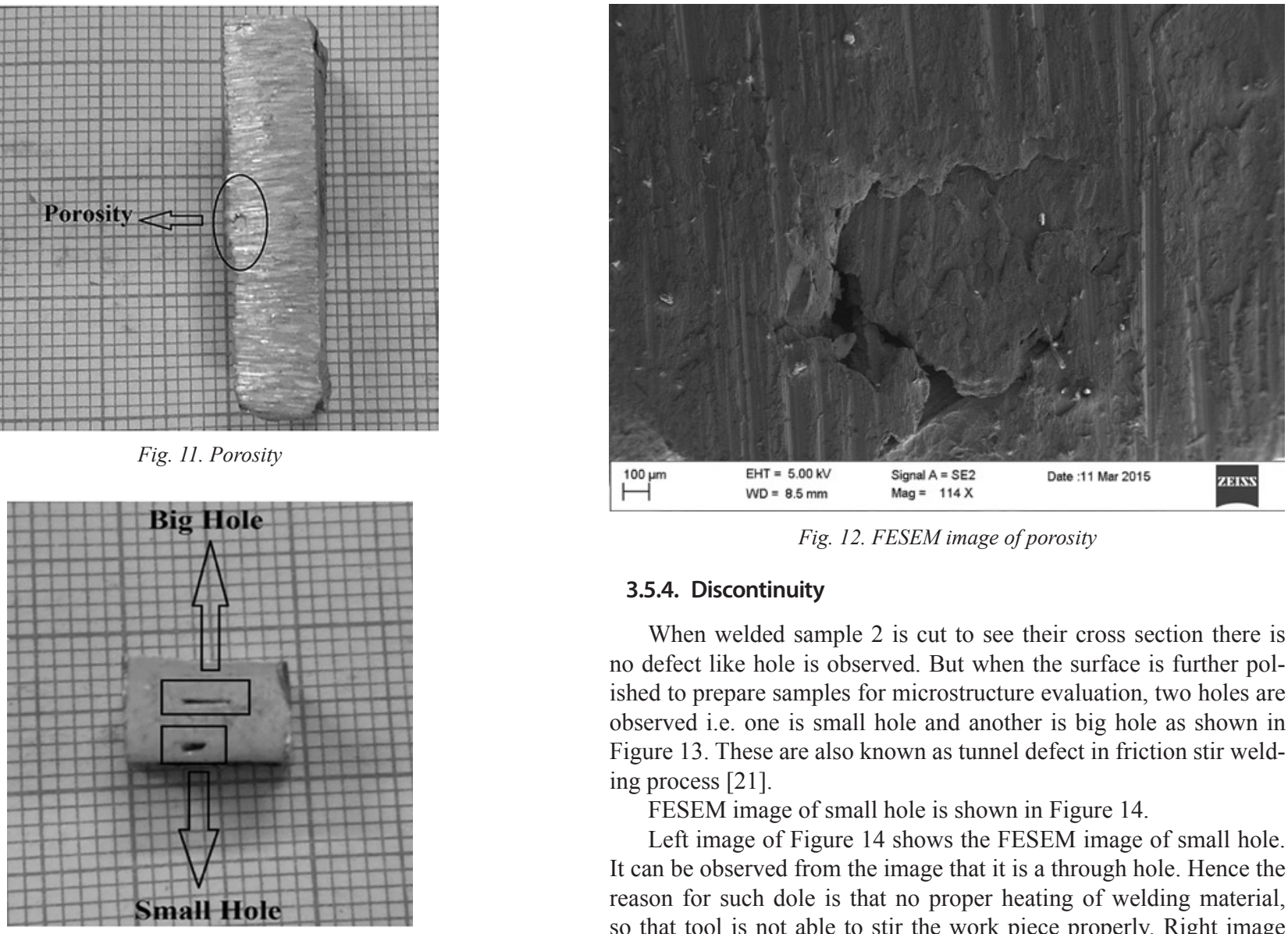

Fig. 12. FESEM image of porosity

\subsubsection{Discontinuity}

When welded sample 2 is cut to see their cross section there is no defect like hole is observed. But when the surface is further polished to prepare samples for microstructure evaluation, two holes are observed i.e. one is small hole and another is big hole as shown in Figure 13. These are also known as tunnel defect in friction stir welding process [21].

FESEM image of small hole is shown in Figure 14.

Left image of Figure 14 shows the FESEM image of small hole. It can be observed from the image that it is a through hole. Hence the reason for such dole is that no proper heating of welding material, so that tool is not able to stir the work piece properly. Right image of Figure 14 shows the magnified view of the circular part as shown in left image. Here irregular
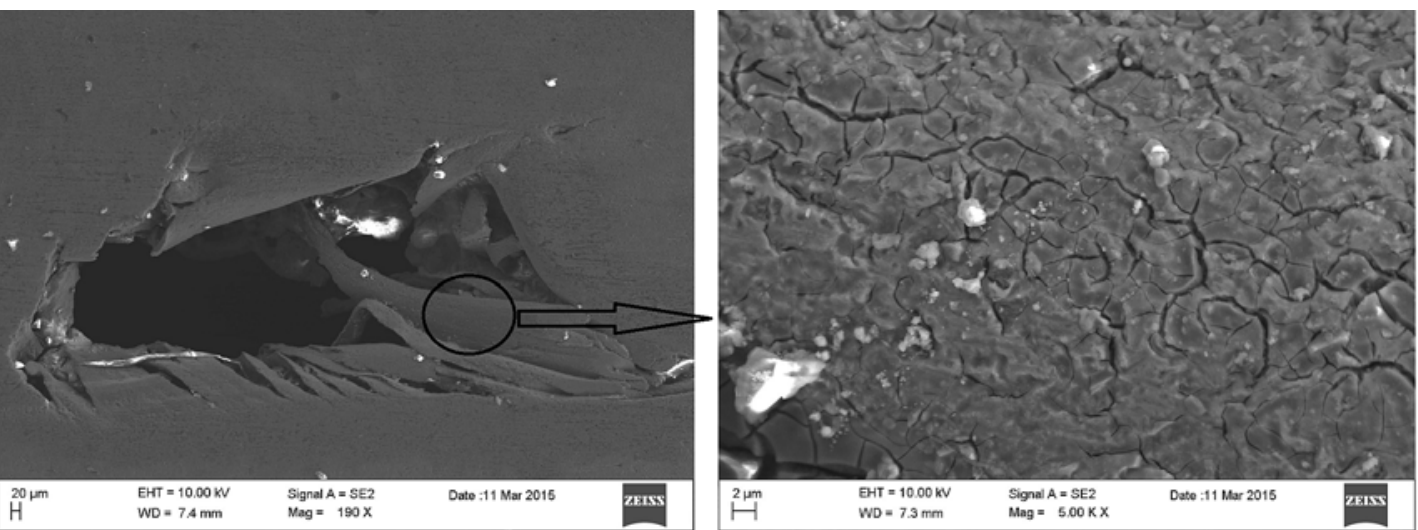

Fig. 14. FESEM image of small hole
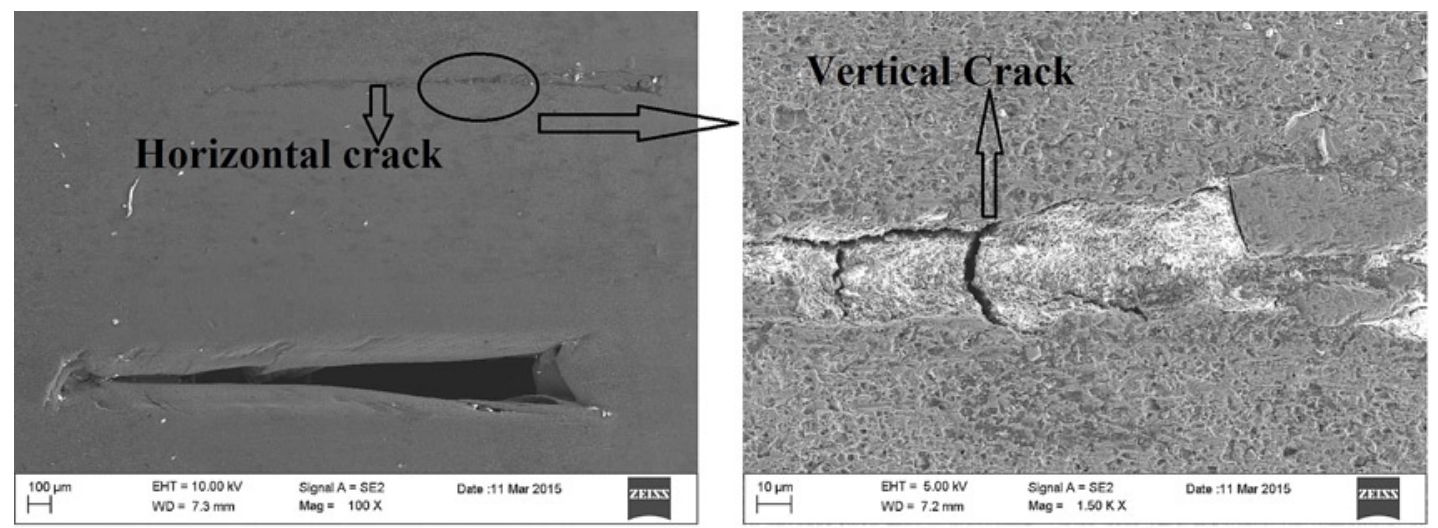
cracks are observed on the surface.

While observing bigger hole through FESEM a crack is spontaneously observed as shown in Figure 15.

On the left image of Figure 15 big hole along with the horizontal crack can be observed. Big hole is also a through hole like small hole. Right image of Figure 15 is the magnified view of the circular part at crack shown in the left image. Further vertical cracks are observed in the horizontal crack. These type of cracks are the main reason for the hole generation and failure of welded parts under wear condition.

Fig. 15. FESEM image of big hole \& crack 


\section{Conclusion and future scope}

From the above study on wear characterization and weld defects of friction stir welding of AA 6061-T6 following conclusions are made.

1. Wear resistance of friction stir welded joint is increased compared to base material. Since material is joined below melting point of material, hence material does not melt during the welding therefore there is no chance of second phase formation.

2. Fracture surfaces of welded joint shows the ductile failure mechanism.
3. At high tool rotational speed (i.e. $1000 \mathrm{rpm}$ ), defect free welds are obtained. Since, at higher rotational speed more heat is generated compared to lower rotational speed (i.e. $500 \mathrm{rpm}$ and $710 \mathrm{rpm}$ ). So material can easily stir and good weld will be obtained at high temperature.

In future wear characteristics and formation of defects at friction stir welded joints; can be studied by the variation of different process parameters like tool tilt angle. Formation of defects during friction stir welding of different materials especially steel can also be analyzed. Remedies of these defects should also be found out.

\section{References}

1. Bernasovsky Peter, Failure analysis of welded components-Importance for technical practice, IIW International congress in central and east European region Slovakia, High Tatras, 14-16 October 2009.

2. Chen Hua-Bin, Yan Keng, Lin Tao, Chen Shan-Ben, Jiang Cheng-Yu, Zhao Yong, The investigation of typical welding defects for 5456 aluminium alloy friction stir welds, Materials Science and Engineering A 2006; 433: 64-69, http://dx.doi.org/10.1016/j.msea.2006.06.056.

3. Dehghani M., Amadeh A., Mousavi S.A.A. Akbari, Investigations on the effects of friction stir welding parameters on intermetallic and defect formation in joining aluminium alloy to mild steel, Materials and Design 2013; 49:433-441, http://dx.doi.org/10.1016/j. matdes.2013.01.013.

4. Dewangan Saurabh, Chattopadhyaya Somnath, Hloch Sergej, Wear assessment of conical pick used in coal cutting operation, Rock Mech Rock Eng 2014; DOI 10.1007/s00603-014-0680-z, http://dx.doi.org/10.1007/s00603-014-0680-z.

5. Dimic Ivana, Arsic Miodrag, Medo Bojan, Stefanovic Ana, Grabulov Vencislav, Rakin Marko, Effect of welded joint imperfection on the integrity of pipe elbows subjected to internal pressure, Technical Gazette 2013; 20: 285-290.

6. Dinaharan I., Murugan N., Influence of friction stir welding parameters on sliding wear behaviour of AA6061/0-10 wt.\% ZrB2 in-situ composite butt joints, Journal of Minerals \& Materials Characterization \& Engineering 2011; 10(14):1359-1377, http://dx.doi.org/10.4236/ jmmce.2011.1014107.

7. Gibson B. T., Lammlein D. H., Prater T. J., Longhurst W. R., Cox C. X.,Ballun M. C., Dharmaraj K. J., Cook G. E., Strauss A. M., Friction stir welding: process, automation and control, Journal of Manufacturing Processes 2004;16: 56-73, http://dx.doi.org/10.1016/j. jmapro.2013.04.002.

8. Glowacz, A., Recognition of Acoustic Signals of Loaded Synchronous Motor Using FFT, MSAF-5 and LSVM, Archives of Acoustics 2015; 40 (2):197-203, http://dx.doi.org/10.1515/aoa-2015-0022.

9. Glowacz A., Glowacz A., Korohoda P., Recognition of monochrome thermal images of synchronous motor with the application of binarization and nearest mean classifier, Archives of Metallurgy and Materials 2014; 59 (1):31-34, http://dx.doi.org/10.2478/amm-2014-0005.

10. Hreha P., Radvanska A., Knapcikova L., Krolczyk G.M., Legutko S., Krolczyk J., Hloch S., Monka P., Roughness parameters calculation by means on-line vibration monitoring emerging from AWJ interaction with material, Metrology and Measurement Systems 2015; Vol. XXII (2):315-326, http://dx.doi.org/10.1515/mms-2015-0024.

11. Janjic M., Vukecevic M., Mandic V., Pavletic D., Sibalic N., Microstructural evolution during friction stir welding of AlSi Mg Mn alloy, Metalurgija 2012;51(1):29-33.

12. Jankauskas V., Kreivaitis R., Milcius D., Baltusnikas A., Analysis of abrasive wear performance of arc welded hard layers, Wear 2008; 265:1626-1632, http://dx.doi.org/10.1016/j.wear.2008.03.022.

13. Jolu T. Le, Morgeneyer T. F., Denquin A., Gourgues-Lorenzon A. F., Fatigue lifetime and tearing resistance of AA2198 Al-Cu-Li alloy friction stir welds: effects of defects, International journal of fatigue 2015; 70:463-472, http://dx.doi.org/10.1016/j.ijfatigue.2014.07.001.

14. Kadlec Martin, Ruzek Roman, Novakova Lucie, Mechanical behaviour of AA 7475 friction stir welds with the kissing bond defects, International Journal of Fatigue 2015;74:7-19, http://dx.doi.org/10.1016/j.ijfatigue.2014.12.011.

15. Karam A., Mahmoud T. S., Zakaria H. M., Khalifa T. A., Friction stir welding of Dissimilar A319 and A413 cast aluminium alloys, Arabian Journal for Science and Engineering 2014; 39:6363-6373, http://dx.doi.org/10.1007/s13369-014-1220-6.

16. Krolczyk G.M., Nieslony P., Krolczyk J.B., Samardzic I., Legutko S., Hloch S., Barrans S., Maruda R.W. Influence of argon pollution on the weld Surface Morphology, Measurement 2015; 70:203-213, http://dx.doi.org/10.1016/j.measurement.2015.04.001.

17. Kuczmaszewski J., Piesko P., Wear of milling cutters resulting from high silicon aluminium alloy cast AlSi21CuNi machining, Eksploatacja i Niezawodnosc - Maintenance and Reliability 2014; 16(1): 37-41.

18. Lakshminarayanan A. K., Malarvizhi S., Balasubramanian V., Developing friction stir welding window for AA2219 aluminium alloy, Transactions of Nonferrous Metals Society of China 2011; 21:2339-2347, http://dx.doi.org/10.1016/S1003-6326(11)61018-2.

19. Lee Won-Bae, Lee Chang-Yong, Kim Myoung-Kyun, Yoon Jung-I1, Kim Young-Jig, Yoen Yun-Mo, Jung Seung-Boo, Microstructures and wear property of friction stir welded AZ91Mg/SiC particle reinforced composite, Composites Science and Technology 2006; 66:15131520.

20. Li. J. Q., Liu H. J., Design of tool system for the external nonrotational shoulder assisted friction stir welding and its experimental validations on 2219-T6 aluminium alloy, International Journal of Advanced Manufacturing Technology 2013;66: 623-634, http://dx.doi.org/10.1007/ s00170-012-4353-3.

21. Lofti Amir Hossein, Nourouzi Salman, Effect of welding parameters on microstructure, thermal and mechanical properties of friction stir welded joints of AA7075-T6 aluminium alloy, Metallurgical and Materials Transactions A 2014; 45A: 2792-2807.

22. Mazurkiewicz D., Computer-aided maintenance and reliability management systems for conveyor belts, Eksploatacja I NiezawodnoscMaintenance and reliability 2014; 16 (3): 377-382. 
23. Mishra R. S., Ma Z. Y., Friction stir welding and processing, Materials science and Engineering R 2005; 50:1-78.

24. Palanivel R., Mathews P. Koshy, Murugan N., Dinaharan I., Prediction and optimization of wear resistance of friction stir welded dissimilar aluminium alloy, Procedia Engineering 2012; 38: 578-584, http://dx.doi.org/10.1016/j.proeng.2012.06.072.

25. Podrzaj P., Jerman B., Klobcar D., Welding defects at friction stir welding, Metalurgija 2015; 54 (2): 387-389.

26. Prakash T., Sivasankaran S., Sasikumar P., Mechanical and tribological behaviour of friction-stir-processed Al 6061 aluminium sheets metal reinforced with A12O3/0.5 Gr hybrid surface nanocomposits, Arabian Journal for Science and Engineering 2015; 40: 559-569, http://dx.doi. org/10.1007/s13369-014-1518-4.

27. Ramulu P. Janaki, Narayanan R. Ganesh, Kailash Satish V., Reddy Jayachandra, Internal defect and process parameter analysis during friction stir welding of Al 6061 sheets, International Journal of Advanced Manufacturing technology 2013; 65: 1515-1528, http://dx.doi. org/10.1007/s00170-012-4276-z.

28. Thomas WM, Nicholas ED, Needhan JC, Murch MG, Templesmith P, Dawes CJ (1991) International patent application PCT/GB92/02203 and GB patent application no. 9125978.9.

29. Wang Wenbin, A stochastic model for joint spare parts inventory and planned maintenance optimisation, European Journal of Operational Research 2012; 216:127-139, http://dx.doi.org/10.1016/j.ejor.2011.07.031.

30. Wojciechowski S., Chwalczuk T., Twardowski P., Krolczyk G.M. Modeling of cutter displacements during ball end milling of inclined surfaces, Archives of Civil and Mechanical Engineering, 2015: 15 (4): 798 - 805 http://dx.doi.org/10.1016/j.acme.2015.06.008.

31. Wojciechowski S., Twardowski P., Wieczorowski M., Surface texture analysis after ball end milling with various surface inclination of hardened steel. Metrology and Measurement Systems 2014; 21(1):145-56, http://dx.doi.org/10.2478/mms-2014-0014.

32. Zhang Huijie, Liu Huijie, Characteristics and formation mechanisms of welding defects in underwater friction stir welded aluminium alloy, Metallography, microstructure and analysis 2012; 1:269-281.

33. ZhaoYong, Zhou Lilong, Wang Quingzhao, Yan Keng, Zou Jiasheng, Defects and tensile properties of 6013 aluminium alloy T-joints by friction stir welding, Materials and design 2014; 57:146-155, http://dx.doi.org/10.1016/j.matdes.2013.12.021.

\section{Ratnesh KUMAR \\ Somnath CHATTOPADHYAYA}

Department of Mechanical Engineering

Indian School of Mines

Dhanbad-826004, India

\section{Sergej HLOCH}

Faculty of Manufacturing Technologies,

Technical University of Kosice,

1 Bayerova St., 08001 Presov, Slovak Republic

Institute of Geonics AS CR, v. v. i.,

Studentska 1768, Ostrava-Poruba, 708 00, Czech Republic

\section{Grzegorz KROLCZYK}

Opole University of Technology

76 Proszkowska St., 45-758 Opole, Poland

\section{Stanislaw LEGUTKO}

Faculty of Mechanical Engineering and Management

Poznan University of Technology

ul. Piotrowo 3, 60-965 Poznan, Poland

E-mail: ratan_876@yahoo.co.in, somuismu@gmail.com, hloch.sergej@gmail.com, grzegorz.krolczyk@wp.pl, Stanislaw.legutko@put.poznan.pl 